\title{
10 let LMS centra - historie a současnost
}

\author{
Martin Paleček \\ Filozofická fakulta \\ Univerzita Hradec Králové \\ Rokitanského 62, 50003 \\ Hradec Králové \\ martin.palecek@uhk.cz
}

Matej Drobňák

Filozofická fakulta Univerzita Hradec Králové Rokitanského 62, 50003

Hradec Králové

matej.drobnak@uhk.cz

V roce 2009 bylo při Katedře filozofie a společenských věd Filozofické fakulty Univerzity Hradec Králové založeno LMS centrum (Language-Mind-Society center). ${ }^{1}$ Letos je to deset let, co LMS existuje a rozvíjí své výzkumné aktivity. Sluší se tedy, abychom $k$ tomuto výročí věnovali několik úvah o jeho minulosti a aktuálním směřování.

Historie LMS sahá do doby nového budování katedry filozofie, respektive přebudování Katedry filozofie a společenských věd z tehdejšího Ústavu filozofie a společenských věd poté, co se od něj odštěpila Katedra sociologie. Stalo se tak krátce po založení Filozofické fakulty UHK v souladu s plány na její rozvoj do plnohodnotné podoby.

Myšlenka založení vědeckého centra byla pozitivně přijata všemi tehdejšími členy katedry. Vzorem pro samotné centrum se stalo obdobné pracoviště na naší partnerské Univerzitě v Oslo. Tam, při katedře filozofie existovalo Centre for the Study of Mind in Nature (CSMN), které dokonce získalo statut norské excelence.

LMS bylo budováno tak, aby odpovídalo badatelským záměrům jednotlivých členů katedry a plánované profilaci hradecké filozofie. Proto byl

1 Informace o aktivitách LMS jsou k dispozici na webových stránkách (LMS Center) a na Facebooku (LMS - Language, Mind, Society Center). Záznamy některých přednášek jsou k dispozici na YouTube (LMS (Language, Mind, Society Center)). 
zvolen i název Language-Mind-Society Center. LMS od samého počátku nemělo pouze dublovat práci samotné katedry. Předpokládali jsme, že centrum bude postupně růst a získá samostatnou pozici na fakultě i univerzitě. Plánem bylo, aby centrum získalo vlastní finanční nezávislost a v budoucnu nabízelo badatelská stipendia, která by bylo možno využít v době sabatiklu jednotlivých akademiků z UHK, ale i mimo univerzitu.

Druhým cílem, který jsme při zakládání centra měli na mysli, byla možnost zvaní přednášejících z jiných, zejména zahraničních univerzit, a tím i možnost rozšírit nabídku přednášek pro posluchače FF UHK.

Třetím cílem mělo být badatelské zapojení studentů, kteří se do práce centra měli zapojit v rámci specifického výzkumu vyhlašovaného FF UHK.

Poslední, čtvrtý cíl měl vyřešit problém spojený s růstem KFSV a celé FF. Věděli jsme, že v případě dynamického rozvoje, značného množství výuky a rozvoje badatelství zákonitě klesá i množství př́ležitostí, kdy jsou jednotliví členové katedry ve vzájemném kontaktu. Proto byly zavedeny tzv. interní semináře, které dodnes slouží k tomu, aby členové katedry informovali kolegy o svém výzkumu a předkládali výsledky své práce kritickým pohledům druhých. Interní semináře měly také sloužit k tomu, abychom se mohli vzájemně informovat o nově publikovaných knihách a článcích v celé šíři svých badatelských záběrů.

Na budování centra byl získán pětiletý grant ze Strukturálních fondů ve výši 4 milionů Kč s další pětiletou udržitelností. Vedoucím katedry byla jmenována vědecká rada LMS centra a prvním vedoucím centra se stal dr. Ondřej Švec, v současné době odborný asistent na Univerzitě Karlově.

Bohužel, některé původní záměry se z různých důvodů nepodařilo naplnit. Na svou finanční nezávislost, badatelská stipendia a další rozvoj centrum dosud čeká. Navzdory tomu můžeme v posledních letech pozorovat jistou konsolidaci. Po odchodu Ondřeje Švece převzal vedení centra Ladislav Koreň a úlohy koordinátora aktivit centra se zhostil Matej Drobňák. Pod tímto vedením, a za podpory FF UHK, centrum začalo novou etapu svého fungování a buduje si svou novou tvář.

Centrum se zaměřuje převážně na pořádání přednášek pro studenty a členy FF UHK. Z programu přednášek je již dnes patrný příklon 
k internacionalizaci centra. Podstatná část přednášek je totiž vedena $\mathrm{v}$ anglickém jazyce. Tento trend je výsledkem dvou faktorů - na jedné straně je to snaha přitáhnout zajímavé a světově známé řečníky na půdu FF UHK, na druhé straně je to výsledek internacionalizace katedry jako takové. Jedním z cílů centra do budoucna je představit studentům řečníky, kteří hýbou současnou filozofií ve světě a které měli studenti doposud možnost poznat jenom zprostředkovaně - ze čtení jejich děl na seminářích. $V$ tomto směru už stojí centrum na pevných základech z minulosti.

Na druhou stranu, badatelský růst katedry vedl k úzké spolupráci s řadou zahraničních výzkumníků a několik z nich našlo na katedře svůj „druhý domov“. To, že jsou interní semináře vedené v anglickém jazyce, tak už dávno není jen výjimkou, která potvrzuje pravidlo. Mezinárodní aktivity členů katedry lákají na katedru i nemalý počet zahraničních badatelů prostřednictvím různých stáží a programů mobilit (zejména Erasmus) - a každý z příchozích je na LMS srdečně vítán.

Mimo to se ale nezapomíná ani na přednášky v českém jazyce, které ocení zejména studenti nižších ročníků. Hlavní snahou je přivést na půdu LMS zajímavá a aktuální témata nejen z filozofie, ale i z př́ibuzných oborů jako jsou antropologie, psychologie, nebo kognitivní vědy. Růst katedry s sebou také přinesl i zvýšení počtu studentů doktorského studia, kteří zde začínají svou budoucí akademickou kariéru a kteří připravují nemalou část přednášek v češtině. LMS centrum se tak často stává prvním místem, na kterém studenti doktorského programu představují svioj projekt a mohou si tak otestovat nejen své rétorické schopnosti, ale i reakce na dotazy v domácí atmosférée.

LMS tak stále slouží především jako platforma pro pořádání přednášek pro studenty a členy univerzity. Vedle toho jsou stabilně vedeny i interní semináře. Za deset let své existence LMS hostilo více než 150 přednášejících, včetně takových jmen jako je Robert Brandom, Huw Price, nebo Martin Kusch, a stalo se nedílnou součástí života Katedry filozofie a společenských věd. Všichni věříme, že to tak zůstane i nadále a do dalších let života mu přejeme jen to nejlepší. 


\section{Informace o aktivitách LMS centra}

Informace o aktivitách LMS najdete na webových stránkách:

LMS Center. Centrum pro studium jazyka, mysli a společnosti

při Katedře filosofie a společenských věd Filozofické fakulty

Univerzity Hradec Králové [online]. Centrum pro studium jazyka, mysli a společnosti, (C) 2009. Dostupné z: http://lms. ff.uhk.cz/

„LMS - Language, Mind, Society Center“ In Facebook [online]. 2015- . Dostupné z: https://www.facebook.com/lmsffuhk/

Záznamy některých z přednášek pořádaných centrem LMS najdete na Youtube:

„LMS (Language, Mind, Society Center)“ In YouTube [online]. 2015- . Dostupné z: https://www.youtube.com/channel/ UCuUqlV4QortVdSAjhinsGig/featured

Paleček, M., Drobňák, M. (2019): „10 let LMS centra - historie a současnost.“ Filosofie dnes 11 (2): 76-79. Dostupné z www.filosofiednes.ff.uhk.cz 